Nikolay Kanev (Veliko Tărnovo)

(iD) https://orcid.org/0000-0003-0570-8078

\title{
Emperor Basil II and the Awarding of Byzantine Honorific Titles to Bulgarians in the Course of THE Conquest of Bulgaria (976-1018)
}

\section{$\mathrm{W}$} ith the establishing of the state centre of Bulgaria south of the River Danube, Byzantium now had a dangerous rival that over nearly three and a half centuries would be the main and, in fact, the sole competitor of the Byzantine Empire for hegemony in the Balkan Peninsula. The Bulgarian state became one of the most important foreign political realities for Byzantium throughout this long period. Regardless of its current state (as well as the current state of the Bulgarian-Byzantine relations), Bulgaria was, to a greater or lesser degree, inevitably a 'thorn in the side' of the Constantinopolitan rulers, if nothing else, because it was the only foreign power, and a considerable one at that, which for purely geographical reasons was always able to permanently threaten the immediate hinterland of the Byzantine capital - that is, the very heart of the empire. Viewed from this perspective, it seems quite logical for Byzantine emperors and elite to have pursued for centuries their dreamed goal of destroying Bulgarian statehood and restoring Byzantine authority as far as the River Danube, a goal which, after numerous unsuccessful attempts to be achieved, during the reign of John I Tzimiskes (969-976) seemed to have been attained at last.

Pretty soon, however, it dawned on Byzantium that the conquering of the eastern limits of the Bulgarian Empire along with the capital Veliki Preslav and the capture of Tsar Boris II and his family not only did not lead to the final destruction of the Bulgarian state, but over the following four decades the latter even became a worthy adversary again as a result of the successful resistance movement of the Kometopuli (Cometopuli) and most of all the energetic and capable reign of Samuel, which, at times, threatened the very foundations of the Byzantine presence in most of the Balkan Peninsula. For the successor to basileus John I Tzimiskes and a legitimate member of the Macedonian dynasty Basil II (976-1025) who at last came to the throne in January 976 - more than a decade and a half after he was declared emperor by his father Romanos II (959-963), the conquest 
of Bulgaria and its placing under permanent Byzantine domination became his main and relentlessly pursued aim, and to the achieving of this aim which eventually had to crown his reign he devoted all his efforts, even turning it to a degree into a fixed idea and the meaning of his life, and thus it is not fortuitous that he went down in history by the sobriquet Boulgaroktonos.

Regardless of the fact that Basil II officially only considered the Bulgarians to be rebels against his authority, he had to use his whole arsenal of possible means - military, diplomatic and other - in order to achieve the final success in the epic, half century long battle for subjugating the Bulgarian state. During the course of this battle, a particularly interesting - and a most effective - tool in this arsenal of means used by Basil II was the awarding of Byzantine honorific titles to members of the Bulgarian elite.

The effectiveness of this tool was due, in the first place, to the more or less high position guaranteed in Byzantine society and in the corresponding court ceremonial which the particular title brought its bearer. In fact, anyone acquainted with the imperial doctrine of Byzantium and the principles of the Byzantine rank hierarchy at the time was aware that the awarding of an imperial titular rank was not just supposed to mean joining an internal state hierarchy, be it of the oldest and most authoritative Christian empire, but admission to the universal hierarchical pyramid itself which was considered the primary building structure of harmony in the oikoumene, in other words - in the entire earthly Christian world.

In the second place, of no less importance was the fact that each Byzantine title was accompanied by its corresponding life annuity - the roga ( $\rho$ ó $\gamma \alpha$ ), which was annually paid in gold by the Byzantine imperial treasury, and the higher the honorific title, the more significant the amount of the accompanying roga was ${ }^{1}$. The roga was a secure and often considerable income, and also paid in money, not in kind, which unlike the primary sources of income for the members of the landowning and the service aristocracy - their lands and the offices they held, depended neither on the vagaries of nature nor on any particular conjuncture, and in no way directly involved carrying out any duties, while its amount was often comparable to or even exceeded the rest of the incomes of the aristocrat or dignitary awarded an honorific title.

\footnotetext{
${ }^{1}$ E.g., the roga which was due to the holder of the title of protospatharios was one litra of gold, that is, 72 nomismata annually, which was quite high an income not only in the time of Basil II; the one accompanying the title of patrikios amounted to the substantial sum of 288 nomismata, while the one for magistros probably even reached the vast amount of 1,116 nomismata annually. On the question of the roga accompanying Byzantine titles, see especially P. LEMERLE, Roga et rente d'état aux $X^{e}-X I^{e}$ siècles, REB 25, 1967, p. 77-100. See also J.-C. CHeynet, Dévaluation des dignités et dévaluation monétaire dans la seconde moitié du XI s., В 53, 1983, p. 469-471; Н. Кънев, Византийската титла магистьр през IX - началото на ХІІ в. Приносът на сфрагистиката за съставяне на листа на носителите на титлата магистьр, [in:] IDEм, Византинобългарски студии, Велико Търново 2013, p. 235-236, note 23.
} 
It is evident then that the appeal of Byzantine titles was in itself great enough, and therefore, by awarding them, the basileus was able to strike powerful chords in human nature, namely the pursuit of honours, a place in society, power and riches. Undoubtedly, Basil II understood well the role of human vanity, avarice and hunger for power as the factor motivating not a few people and took advantage of that whenever it was possible, so in this respect awarding honorific titles was for him a perfect tool, which he used judiciously, with foresight and - usually - with great success ${ }^{2}$. Like his predecessors, Basil II used this tool in a very wide geographical area: from Italy in the west to the Armenian and Georgian lands in the east, but unlike them, he was the only Byzantine basileus to make extensive use of awarding Byzantine honorific titles in his relations with the Bulgarians, and it can be asserted confidently that this was entirely placed in the context of the conquering of Bulgaria and making the Bulgarians Byzantine subjects. Certainly, for Constantinopolitan rulers the awarding of Byzantine titles to aristocrats and rulers 'foreign' to the empire meant in principle their accepting Byzantine suzerainty, but did not of itself necessarily imply the loss of independence for the estates of the 'foreign' person awarded a Byzantine title and their direct incorporation into the Byzantine Empire, and quite often marked more or less specific vassal relations.

It should be emphasized, however, that at the end of the $10^{\text {th }}$ century and in the first two decades of the $11^{\text {th }}$ century when the policy of Basil II of awarding honorific titles regarding the Bulgarians was carried out, there was no such option of preserving independence, and in each case awarding a title could only and without exception have entailed subordination to Byzantium and acknowledging the direct authority of the basileus - i.e. renouncing the cause of Bulgarian independence and statehood. In this respect, of utmost importance for Basil II were undoubtedly those cases in which members of the Bulgarian imperial family were awarded high Byzantine titles.

\footnotetext{
${ }^{2}$ This can be traced well both in terms of internal policy and foreign policy. With regard to internal policy, highly characteristic is the way in which in 989 Basil II dealt with Bardas Skleros: the latter agreed to renounce forever his claim to the emperor's crown in exchange of a number of privileges, the first among which was his being awarded the extremely high title of kouropalatēs, which belonged to the higher order of titles in Byzantium (see JeAn Skylitzès, Empereurs de Constantinople, trans. B. Flusin, comm. J.-C. Cheynet, Paris 2003 (cetera: Skylitzès), p. 283. On Bardas Skleros, see W. SеIвт, Die Skleroi. Eine prosopographisch-sigillographische Studie, Wien 1976, p. 29-58). On the use of Byzantine honorific titles as a tool in foreign policy during the reign of Basil II, see, е.g., Н. Кънев, Византинобългарски студии..., р. 66-72, 245-246, 248; ІDем, Куропалати извън Византийската империя през IX-ХІ век, Епо 11, 1/2, 2003, р. 82-83, 85.
} 


\section{The awarding of Byzantine titles from the hierarchy for the eunuchs to Roman of Bulgaria}

Boris II's brother Roman of Bulgaria was one of the members of the Bulgarian imperial dynasty who was awarded high Byzantine titles and was the first such member with regard to whom Basil II used the tool under consideration ${ }^{3}$. In 971, together with his elder brother Boris (who, after having been deprived of imperial dignity, was awarded the high title of magistros by John I Tzimiskes ${ }^{4}$ ), he was taken to Constantinople where he remained in honorable captivity until 976 or 977 when the two brothers fled to the free Bulgarian lands. Unlike his elder brother, sources do not indicate that during this period Roman was awarded any Byzantine titular rank and most likely this is due to the fact that he was not awarded one. The silence of the sources is not the only reason to believe that Boris II's younger brother was not awarded a Byzantine honorific title at that time. Bearing in mind that, still, he was not equal in status to his elder brother and the then head of the Bulgarian imperial family, and that Boris, as noted above, was awarded the rank of magistros, theoretically Roman could only have been awarded the title of patrikios, which was hierarchically high enough and equally accessible both to eunuchs and non-eunuchs. A lower titular rank than the one of patrikios would not have been possible in this case at least because it would not have been suitable for a member of the Bulgarian imperial family - even though former by then - who, at the same time, was a comparatively close relative of the Byzantine imperial dynasty, and furthermore a lower title would not at all have corresponded to the very high one conferred on Boris II after his dethronement. It is known, however, that after his recapture in 991 Roman was awarded the titles of patrikios and praipositos by Basil II, which clearly shows that he did not have them before, and therefore in 971, after he was taken to Constantinople, he was not awarded any rank title 5 .

\footnotetext{
${ }^{3}$ It is not impossible to assume that a few years earlier Basil II offered an honorific title to Samuel's brother Aaron, but this, firstly, can only be an assumption as it is not attested in the sources, and, secondly, even if Basil II tried to use bestowing a certain honorific distinction on Aaron in order to win him over, still, the latter at that time was not considered a member of the Bulgarian imperial dynasty (even with regard to the perfectly possible kinship between the Kometopuli and the Kroum dynasty), so Roman was the first indisputable member of the imperial family who was awarded titular ranks by Basil II.

${ }^{4}$ See Лев Диакон, История, ed. Г.Г. Литаврин, Москва 1988, p. 83; Ioannis Scylitzes, Georgios Cedrenus, Historiarum compendium, [in:] FGHB, vol. VI, ed. G. Cankova-Petkova et al., Serdicae 1965 (cetera: Scylitzes-Cedrenus), p. 274.

${ }^{5}$ In view of the close kinship of Roman with the still underage at that time legitimate emperors from the Macedonian dynasty Basil II and Constantine VIII (Roman's maternal grandfather Christopher Lekapenos and Basil II and Constantine VIII's paternal grandmother Empress Helena Lekapene were brother and sister), a possible awarding of a comparatively lower title to Roman would have damaged not only his personal prestige (as well as the prestige of the Bulgarians and their imperial family more
} 
After Boris II's untimely death, Roman remained the last male member of the imperial family of the direct line of descent, and together with Samuel led the struggle of the Bulgarians against Byzantium, residing in Skopje until his capture in 991. Since, while still very young, he was castrated during his stay in Constantinople in 962-963 on the order of the parakoimomenos Joseph Bringas $^{6}$, in view of the tradition that eunuchs could not ascend the throne, Roman was probably never crowned Tsar of Bulgaria, although it is not impossible that he received entirely legitimately a imperial title while still very young - before his father died and before he was castrated, if we assume that together with his brother Boris they had been proclaimed co-rulers by Tsar Peter I ${ }^{7}$. Although by that time Roman had long been castrated, the Bulgarians respected the imperial rights of the last direct descendant of the dynasty and he had the supreme

generally), but it would ultimately have lowered also the prestige of the Byzantine basileis themselves and of the Empire. From this perspective, it was more acceptable to John I Tzimiskes not to award Roman of Bulgaria any titular rank rather than conferring a lower one on him. Also, it would be difficult to assume that Roman received the titles of patrikios and praipositos in 971 and they were taken away from him 'in his absence' after his flight to the Kometopuli in 976/977, and that in 991 he received them again by Basil II, at least because it is emphasized in the sources it was Basil II who awarded him these titles, not that they were restored to him or conferred on him again.

${ }^{6}$ In some scholars' opinion, Roman was castrated not on the order of Joseph Bringas in 963, but after the Bulgarian imperial family were captured and taken to Constantinople in 971, on the order of John I Tzimiskes who wanted to make doubly sure that the Bulgarian dynasty would come to an end since Tsar Boris II had no sons, and Roman as being castrated also had no chance of producing progeny - see Й. АНДреЕв, И. ЛАЗАРОв, П. ПАвЛОв, Кой кой е в средновековна България, София 2012, p. 576. Such a dating can also provide part of the explanation as to why Roman did not receive a honorific title by John I Tzimiskes in 971, especially if his castration had initially to be kept secret, as the ceremony of awarding Byzantine ranks itself, as a rule, showed whether the particular rank was from the hierarchy for eunuchs or from the one for non-eunuchs - i.e. whether the person awarded was castrated or not. On the Byzantine rank hierarchy in this period, see Н. Кънев, Византийският йерархичен модел от IX-XI в., АДСВ 39, 2009, p. 142-163.

${ }^{7} \mathrm{I}$ believe this assumption would definitely resolve the apparent contradiction between the fact that it was impossible for a castrated person to be proclaimed tsar and that, at the same time, the sources attest to Roman's being a eunuch and Tsar of the Bulgarians. If, together with his brother Boris, Roman was proclaimed tsar and co-ruler by his father Peter when he was still a Bulgarian prince of full value, that is, before he was castrated by the Byzantines, then he received entirely legitimately his imperial title at the time when there was no obstacle for him to be proclaimed tsar. In this situation, he had already had the rank of tsar at the time he was made eunuch, and, at least to the Bulgarians, he could have only been stripped of his rank by the legitimate Bulgarian tsar-autocrat. Bearing in mind the circumstances surrounding Roman's castration and that there was no opportunity whatsoever for the legitimate taking away of his imperial title in 971-977, as well as later - when he was already the only direct descendant of the imperial dynasty, to the Bulgarians he apparently continued to be tsar until his very death. To the Byzantines, however, Roman was certainly not tsar and it was not by chance that he is not called as such in the Byzantine sources. For a comprehensive review of the scholarly discussion and the opinions expressed about whether Roman was a tsar or not (and of the relevant sources), see А. Съвотинов, България при иар Самуил и неговите наследници (976-1018), vol. I, София 2008, p. 574-590. 
authority in the state, really ruling together with Samuel. It is no coincidence that Samuel did not use the title Bulgarian tsar and autokrator before Roman's death in 997. Having been taken into Byzantine captivity for a second time, Roman was awarded the high titles of patrikios and praipositos by Basil II, and was appointed strategos of Abydos. At the time of his awarding, the dignities of patrikios and praipositos were virtually the two highest titles for a eunuch in the rank hierarchy of the empire because after 985 for forty years - until the death of Basil II, there were no holders of the title of proedros, a title which in this period was purely formally leading the hierarchy of rank positions accessible to eunuchs: because of the basileus's unwillingness to name whoever it may have been as proedros, the title was actually out of 'hierarchical' circulation as long as December 1025 or the beginning of $1026^{9}$. Roman's position in the governance of Bulgaria, whatever its dimensions may have been, was undoubtedly a legitimizing factor in Samuel's struggle against Byzantium. From this perspective, to Basil II awarding the two high titles was neither only a compensation to Roman for having been deprived of his position nor just bestowing high honours on him as befitted a close relative after all. It was intended most of all to serve as a demonstration and a hint to the Bulgarians: since the last direct descendent of the legitimate imperial dynasty had become a patrikios and a praipositos and especially since he had become the strategos of Abydos - i.e. an official of the Emperor's and a high-ranking officer in the provincial administration of the empire, then he had recognized the basileus's authority as a subject of his. Consequently, submitting himself, he also submitted Bulgaria to Byzantine authority, which meant, therefore, that further struggle and Samuel's authority were illegal, while those who would submit themselves to Basil II, like Roman, would benefit from the Byzantine basileus's benefactions and benevolence.

\footnotetext{
${ }^{8}$ See Scylitzes-Cedrenus, p. 283. On Roman see also Й. АНдревв, И. ЛАЗАров, П. ПАвЛов, Кой кой е..., p. 576-577; И. Божилов, Българите във Византийската империя, София 1995, p. 350, № 440 (and the bibliography given there).

${ }^{9}$ Since 963, above the titles of patrikios and praipositos in the hierarchy for the eunuchs was the newly introduced title of proedros, but after the death of its first holder - the illegitimate son of Romanos I Lekapenos Basil, who being a brother of the grandmother of the ruling basileus Basil II was among the closest relatives of this emperor, the latter, without abolishing this highest title for eunuchs, 'took it out of use' and, in practice, patrikios and praipositos in the period 985-1025 were again the two highest titular levels accessible to eunuchs, as it was the case until 963 . Virtually the same situation as with the title of proedros was also the one with the other two high titles introduced at the time of Nikephoros II Phokas which were accessible to eunuchs - vestarches and vestes: their use in the hierarchy for the eunuchs was also 'frozen' for a long time by Basil II without them being abolished, and for the last one or two decades of the $10^{\text {th }}$ as well as the first years of the $11^{\text {th }}$ century there is no reliable evidence of any promotions of eunuchs to the titles of vestarches or vestes. On the honorific title of proedros, seе Н. Кънев, Титлата проедър като част от пврворазредните почетни титли във Византия през X-XI в. Проедри и протопроедри, засвидетелствани по сфрагистични данни, [in:] Ірем, Византинобългарски студии..., p. 144-227. On the titles of vestes and vestarches, see the references given in note 33 below.
} 


\section{Samuel's daughter Miroslava and her husband}

The next instance of awarding a member of the Bulgarian ruler's family a Byzantine honorific title also served the political line of destroying the Bulgarian state that was determinedly followed by Basil II. In this case, however, for the first time in the history of Byzantine-Bulgarian relations, the person to be awarded an honorific title was not a man, but a woman - Samuel's daughter Miroslava ${ }^{10}$, who was actually the first foreign woman in Byzantium to receive the title of zoste patrikia $^{11}$. Miroslava was married to the Byzantine aristocrat and ethnic Armenian Ashot Taronites taken captive by her father in 995, the son of the Thessalonikan doux Gregory Taronites who was killed by the Bulgarians, because, according to John Skylitzes's account, she had been so deeply in love with him that even threatened Samuel she would kill herself if he did not join her in lawful marriage with Ashot.

In actual fact, Samuel's son-in-law was only a second generation Byzantine aristocrat and direct descendant of the dynasty - dethroned only about thirty years earlier - of the Armenian principality of Taron ${ }^{12}$ that was annexed by Byzantium during Nikephoros II Phokas' reign. The Taronites, including Ashot's father and uncle, were some of the strongest supporters of the mutineer Bardas Skleros in his struggle against Basil $\mathrm{II}^{13}$. It is possible that Samuel, who was also of Armenian descent on the maternal side, believed he could rely on the descendant of the princes of Taron in his struggle against Byzantium not only because of his daughter's love for him and that is why he put his new son-in-law in charge of the governance and defence of the Dyrrachion district. Soon after the wedding, Ashot and Miroslava left for Dyrrachion. There, however, Samuel's daughter was persuaded by her husband to defect to the basileus and the couple fled on board a ship of the Byzantine fleet located near Dyrrachion. After their arrival in Constantinople, Emperor Basil II awarded Ashot the highest possible honorific title accessible at the time to a person not belonging to the Imperial

\footnotetext{
${ }^{10}$ On Miroslava, see Scylitzes-Cedrenus, p. 279. Cf. И. Божилов, Българите..., p. 331, № 401; Й. АНДРЕЕВ, И. ЛАЗАРОВ, П. ПАВЛОВ, Кой кой е.., p. 471.

${ }^{11}$ On the title of zoste patrikia (or just zoste, as it quite often occurs in written sources), see A. VogT, Histoire des institutions: note sur la patricienne à ceinture, EO 37, 1938, p. 352-356; R. GuILLAND, Contribution à l'histoire administrative de l'empire byzantin. La patricienne à ceinture, $\dot{\eta} \zeta \omega \sigma \tau \grave{\eta} \pi \alpha \tau \rho$ кía, Bsl 32, 1971, p. 269-275; J.-C. Cheynet, Patricienne à ceinture: une femme de qualité. Au cloître et dans le monde. Femmes, hommes et sociétés (IX $-X V^{e}$ siècle), [in:] Mélanges en l'honneur de Paulette L'Hermite-Leclercq, Paris 2000, p. 179-187; Н. Кънев, Византийската титла патрикия-зости (IX-XI в.). Приносът на сфрагистиката за попвлване на листата на носителките на титrama, И 4, 2011, p. 173-198.

${ }^{12}$ The independent Armenian principality of Taron (whose princely family was called in Byzantium by the name Taronites) was incorporated into the Empire during Nikephoros II Phokas' reign in 967/968. Seе К.Н. ЮзБАшян, Армянские государства эпохи Багратидов и Византия IX-ХI вв., Москва 1988, р. 125, 175.

${ }^{13}$ Ibidem, p. 125.
} 
family, namely magistros. What is more interesting in this case, however, is the fact that Miroslava was elevated to a position higher than that of her husband's as she received by Basil II a title two levels higher - zoste patrikia - belonging to the highest and most inaccessible class of titles in the rank hierarchy of Byzantium which were awarded very rarely and were, as a rule, only reserved for the closest relatives and the members of the basileus' family. The dignity of zoste patrikia was the only Byzantine title intended for women, and until then all its holders had been in a direct family relationship with the ruling emperor. It was considered so high that it was quite often left 'vacant' as no available candidate was worthy enough of it and of suitable descent.

Very relevant, in this situation, is the question why Samuel's daughter was awarded such a high title by Basil II. As the wife of one of only a few magistroi in the empire at that time, Miroslava was already of high enough standing, ranking, along with the few other magistrisses, immediately after the princesses of the Macedonian dynasty and therefore above all the other members of the Byzantine elite. Why then Basil II, who demonstrated consistent conservatism in following the rules and principles of the imperial rank hierarchy, made such a significant concession going beyond the achieving of the possible political goals of the act in question and created a double precedent: on the one hand, allowing the title of zoste patrikia to be borne for the first time by a foreign woman, even if a princess, and, on the other hand, for the first time again, the zoste patrikia was not a direct blood relative of or a closest relation to the basileus?

Awarding Miroslava the dignity of zoste patrikia was recognition of her imperial descent, yet this by no means meant Basil II regarded Samuel as a legitimate Bulgarian tsar. On the contrary, for the basileus of the Byzantines the end of the Bulgarian Empire was already brought with the dethronement of Boris II by John I Tzimiskes in 971, and the Bulgarians struggling against Byzantium were only rebels and secessionists from his authority. The imperial descent of Samuel's daughter was, undoubtedly, traced through the line of her grandfather komit Nikola's relation to the Bulgarian imperial dynasty, which in turn, through the marriage of Tsar Peter I to Maria/Irene Lekapene (whose father was a brother of Empress Helena, Basil II's grandmother), was in close family relationship not only to the Lekapenoi, but also to the Macedonian dynasty in Byzantium. Thus, Miroslava not only had the blood of the Bulgarian imperial family in her veins, but she was also a female relative, although not so close, of the Byzantine basileus Basil II himself, so by awarding the Bulgarian princess the dignity of zoste patrikia he did not really go against the established traditions very significantly concerning this particular high title, and did not create such a precedent as it may seem on the face of it. In a way, Basil II's actions in the case of Samuel's daughter followed the same Byzantine course of action as with all the other members of the Bulgarian imperial house during the period 971-1018 who received Byzantine 
honorific titles, and did not differ considerably from the manner the cases of Boris II and Roman were dealt with.

At the same time, it should be emphasized that in this case, too, Basil II was aiming at a very specific effect by awarding Miroslava this particular high title - an effect that would have been difficult to bring about by any other means and which was undoubtedly related to the particular picture the situation in Bulgaria provided and the development of the Bulgarian-Byzantine conflict. The time of Miroslava's awarding coincided chronologically with a new stage of Samuel's reign when Roman could no longer have been used as a legitimizing and stabilizing factor of the Bulgarian statehood in his capacity as the formal head of the Bulgarian state, and, therefore, Samuel had a period ahead of him during which he now had to win recognition from his subjects as Bulgarian tsar and autocrat. It is during this period that Basil II, using Ashot Taronites and Miroslava's flight, had the chance through the latter to make a move which got a powerful message across to Samuel's subjects. Awarding Samuel's daughter the title of zoste patrikia, Basil II brought about a much more powerful effect than if he had contented himself with only awarding Ashot the title of magistros, thus making Miroslava magistrissa, because Miroslava's flight to Byzantium might itself, after all, have been regarded as a deeply moving love affair in which the love for and devotion to one's husband exceeded the love for and loyalty to one's father, and, viewed from this perspective, it did not damage so much Samuel's prestige and authority among the Bulgarians. If Basil II had contented himself with only elevating Ashot to the rank of magistros, it would have seemed that it was Ashot who ultimately betrayed the Bulgarian cause and defected to the Byzantine side, while his wife was rather the victim of her love - i.e. her flight to Byzantium would have had in itself a much more modest effect as a message to the Bulgarians and as a call for rejecting Samuel and defecting to Basil II's side. Accepting, however, the title of zoste patrikia - i.e. the only specifically 'lady's title' in Byzantium, Miroslava received a Byzantine rank not as someone's wife (as in the case of magistrissa, which did not directly require her own consent since she became one as the wife of a magistros), but in her personal capacity, thereby expressing most clearly her recognition of the Byzantine basileus's authority in exchange for the extremely high position in the imperial hierarchy bestowed on her. With this, Basil II undoubtedly dealt a very serious blow to the Bulgarian ruler and sent a very powerful message to the rebellious Bulgarians trying to convince them that since even Samuel's own daughter did not recognize him as a tsar and voluntarily submitted to the basileus, whose authority she regarded as legitimate, then Samuel was not a tsar at all, but only a mutineer and usurper, and that the Bulgarians must not obey him, but must stop the struggle against Byzantium and submit to the legitimate emperor Basil II as Samuel's daughter herself had done. At the same time, demonstrated again were Basil II's generosity and goodwill to all who had voluntarily submitted 
to him - i.e. it is evident that the message in the case of awarding Miroslava the high title was multifaceted and with lasting effect, and was certainly a carefully calculated blow on the part of the Byzantine basileus to Samuel's legitimacy as Bulgarian tsar, which to Basil II justified the significant concession he made to Miroslava elevating her to the rank of zoste patrikia.

\section{The awarding of Byzantine titles to the members of the Bulgarian imperial family in 1018}

The concluding episode in the Byzantine course of action we traced above consistently followed by Basil II concerning the members of the Bulgarian imperial family came in 1018. It was a kind of repetition on a larger scale of what happened in 971 and symbolized above all the final subjugation of Bulgaria by Byzantium. After Tsar Ivan Vladislav's death (1015-1018) at the siege of Dyrrachion in February 1018, his widow Maria declared her readiness to capitulate to Basil II through the mediation of the Bulgarian Church's primate David ${ }^{14}$, and soon after that - after the surrender of Ohrid - bringing her three younger sons and six daughters, she presented herself before the basileus who 'raciously received her and ordered to be guarded deferentially ${ }^{15}$. The former tsarina was awarded the title of zoste patrikia ${ }^{16}$, and on Basil II's return to Constantinople took part in the Emperor's triumph, like Boris II in 971, walking ahead of the basileus - the victor and conqueror of Bulgaria ${ }^{17}$. Again, as in the previous case with Samuel's daughter Miroslava, what catches the attention is the extremely high dignity bestowed on Maria. Within only about twenty years, two members of the Bulgarian imperial family became zostai patrikiai, occupying, on the one hand, the highest possible position in the Byzantine system of rank precedence for women, and becoming, on the other hand - in view of their title - the highest ranking persons in hierarchical terms among the imperial elite at the end of the $10^{\text {th }}$ and the first quarter of the $11^{\text {th }}$ century, ranking immediately after the two emperors Basil II and Constantine VIII and after Constantine VIII's three daughters. And since the title of zoste patrikia was single - i.e. there could not be more than one holder at one and the same time, its bestowing on Tsar Ivan Vladislav's widow indicates that it was vacant at that time which means the previous known zoste patrikia Miroslava was most probably not among the living.

\footnotetext{
${ }^{14}$ Scylitzes-Cedrenus, p. 290-291: Immediately after that the emperor approached Strumitsa and the Archbishop of Bulgaria David came up to him with a letter from Maria - Ivan's wife, who was promising to renounce Bulgaria if her requests were granted. On Maria, see И. Божилов, Българиme..., p. 249-250, № 167; see also Й. АНДРеЕв, И. ЛАЗАРОв, П. ПАвЛОв, Кой кой е..., p. 446-447.

${ }^{15}$ Scylitzes-Cedrenus, p. 291-292.

${ }^{16}$ Scylitzes-Cedrenus, p. 295.

${ }^{17}$ Scylitzes-Cedrenus, p. 296.
} 
Despite their mother Mariya's capitulation to Basil II and the submitting of the capital Ohrid and nearly all Bulgarian territories to his authority, Ivan Vladislav's three elder sons - Prusian (or Presian II who, even though having reigned for a short time, should technically be considered the last Bulgarian tsar before Bulgaria's final submission to Byzantine authority), Aron and Alusian - managed to flee into the Tomor mountain and carried on the anti-Byzantine struggle as some of the last defenders of Bulgarian independence. After a prolonged siege, later in the same 1018 they surrendered to Basil II, who received them in Devol on a high tribune, calmed them with favourable and kind words and honoured them with high titles: Prusian - with magistros, and his brothers - with patrikios ${ }^{18}$. The Bulgarian princes became part of the highest stratum of the Byzantine rank elite, which then consisted of the comparatively limited number of the title holders in the range magistros to patrikios. As magistros, in view of the current picture of the rank ordering in the system of court precedence, Prusian was one of a very few holders of the high dignity, who were at the very top of this hierarchical order and above whom there were only one higher ranking person in the hierarchy - the zoste patrikia - the former tsarina Maria of Bulgaria who, as noted above, was occupying the position immediately following those who were above all earthly hierarchy - the Byzantine emperors and the porphyrogennetai (purpleborn) princesses, Constantine VIII's daughters.

In fact, Prusian's mother was the only person at that time that had a higher honorific title than her son's - both within Byzantium itself and beyond it in the countries where the awarding of Byzantine titles to members of the local ruling dynasties was traditionally used as an element of the empire's foreign policy.

On the one hand, by awarding high titles to the members of the Bulgarian imperial family in 1018, Basil II was undoubtedly trying to incorporate them into the highest stratum of the Byzantine elite and thus finally eliminate the leadership of the Bulgarians' struggle against the imposing of Byzantine authority. On the other hand, bestowing high Byzantine rank distinctions on the former Bulgarian tsarina and the Bulgarian princes Prusian, Aron and Alusian by Basil II does not seem anything out of the ordinary, at least in view of the number of precedents set since 971 .

\section{The awarding of Byzantine titles to members of the Bulgarian aristocracy as part of Basil II's policy of subjugating Bulgaria}

Besides the members of the imperial family, Byzantine honorific titles in this period were also bestowed on members of the Bulgarian aristocracy. During the first two decades of the $11^{\text {th }}$ century when he concentrated all his efforts on the struggle for subjugating Bulgaria and especially in the last years of this struggle, Basil II

${ }^{18}$ Scylitzes-Cedrenus, p. 292. 
Boulgaroktonos made efficient use of awarding Byzantine honorific titles in order to win over some of the most prominent and important nobles. The high titular dignities awarded to members of the Bulgarian elite were part of the price paid for recognizing the empire's authority. Among the Bulgarian nobles who were awarded honorific titles by Basil II in the process of conquering Bulgaria might be mentioned Nikulitsa ${ }^{19}, \mathrm{Krakra}^{20}$, Bogdan ${ }^{21}$, Dragomŭzh ${ }^{22}$, the brothers Nicholas and Teodor Chryselios ${ }^{23}$, Dimitŭr Polemarh (Demetrios Polemarchos) ${ }^{24}$, and Elemag $^{25}$, who were awarded the rank of patrikios, and Dobromir, who was even

${ }^{19}$ Scylitzes-Cedrenus, p. 281. See also И. Божилов, Българите ..., p. 347, № 432; Й. Андревв, И. ЛАЗАРОВ, П. ПАВЛОВ, Кой кой е..., p. 520-521.

${ }^{20}$ Scylitzes-Cedrenus, p. 290. See also И. БоЖилОв, Българите..., p. 322, № 391; Й. АндреЕв, И. ЛАЗАРОВ, П. ПАВЛов, Кой кой е..., p. 404-405.

${ }^{21}$ Scylitzes-Cedrenus, p. 291. See also И. Божилов, Българите..., p. 229, № 132; Й. Андреєв, И. ЛАЗАРОВ, П. ПАВЛОВ, Кой Кой е..., p. 70.

${ }^{22}$ Scylitzes-Cedrenus, p. 290. On him, see also И. Божилов, Българите..., p. 306-307, № 341; Й. АНДРеЕВ, И. ЛАЗАРОВ, П. ПАВЛОВ, Кой кой е.., p. 193.

${ }^{23}$ Sons of the proteuon of Dyrrachion, John Chryselios. Their Bulgarian descent is beyond any doubt. In 1005 (or 997?) Samuel's son-in-law who had fled from Dyrrachion, Ashot Taronites, brought Basil II a letter from John Chryselios in which John was promising the basileus to surrender the city to him if he was honoured together with his sons with the title of patrikios. The emperor confirmed by a letter that he would fulfil his promise, and Dyrrachion was surrendered to 'patrikios' Eustathios Daphnomeles. Chryselios's sons were awarded the title 'patrikios' since he had already died. See Scylitzes-Cedrenus, p. 279-280. See also Й. Андревв, И. ЛАзАров, П. ПавЛов, Кой кой е.., p. 517; И. Божилов, Българите..., p. 356, № 452 and № 453 (and the bibliography given there).

${ }^{24}$ On him, see В.Н. ЗлАТАРСКИ, История на българската държава през средните векове, vol. I.2, София 1971, p. 647, 681; Й. АНДРЕЕв, И. ЛАЗАРОВ, П. ПАВЛОВ, Кой кой е..., p. 172-173.

${ }^{25}$ At the time of Ivan Vladislav, Elemag was governor of Belegrad (today Berat in Albania, not Belgrade on the Danube - sеe Г. Николов, Едно сведение за българската история: Ioannes Scylitzes (Cod. Ambr. C. 279), [in:] Civitas Divino-Humana. В чест на професор Георги Бакалов, София 2004, p. 335-338) and was one of the last Bulgarian nobles to surrender to Basil II. He has been attested as patrikios in relation to the plot in Thessaloniki in 1019 to restore the Bulgarian Empire (together with Gavra) but, undoubtedly, he received the title before that - when he submitted to the basileus in 1018. See Scylitzes-Cedrenus, p. 296, $\beta$. Сf. И. Божилов, Българите..., p. 115-116 and p. 307-308, № 343; Й. АНДРеЕв, И. ЛАзАРОв, П. ПАвЛОв, Кой кой е.., p. 208-209. This case shows that it is perfectly possible that other Bulgarian nobles, too - of whom Skylitzes mentions that they submitted to the emperor without referring to any titles they were awarded - actually received such titles by Basil II. Regarding patrikios Gavra who participated with Elemag in the plot in Thessaloniki mentioned above and is sometimes numbered among the Bulgarian boyars (В. ЗлАТАРСКИ, История..., vol. І.2, p. 742; Й. АндРЕЕВ, И. ЛАЗАРов, П. ПАвЛОВ, Кой кой е..., p. 129; Т. СлАвовА, Владетел и администрация в ранносредновековна България. Филологически аспекти, София 2010, p. 290), more plausible seems the argument for him being of non-Bulgarian descent, which is why Ivan Bozhilov did not include him in the prosopographical catalogue of his monograph on the Bulgarians in Byzantium (sеe И. Божилов, Българите..., p. 116 and 129, note. 52; on the origin 
granted a title higher than patrikios - the title of anthypatos ${ }^{26}$. Worth noting is the fact that all the Bulgarian boyars mentioned received very high titles - not a single one of them was at a level lower than patrikios which is an indication, in the first place, of how substantial concessions Basil II was ready to make for the sake of achieving his ultimate goal. Apart from the persons listed above, in the final stage of conquering Bulgaria in 1018 Byzantine honorific titles which were significant enough, but not of the first order ${ }^{27}$, were granted to some members of the younger generation of Bulgarian aristocrats. Nikulitsa the Younger, who was the son of Samuel's renowned associate of the same name and who surrendered to Basil II in Skopje in 1018 like Lazaritsa, the young Dobromir and Nestoritsa did a little bit later ${ }^{28}$, is an example of a Bulgarian noble who received a prestigious honorific title which, however, did not belong to the class of the titular ranks of the first order in Byzantium. As John Skylitzes notes, he was granted the title of protospatharios and the office of strategos by the basileus ${ }^{29}$.

Certainly, it was far from always being the case that the Bulgarians who received the high titles became loyal subjects of the basileus as the case of Nikulitsa the Elder (the father of Nikulitsa the Younger) demonstrates, who, ignoring Basil II's benefactions (including the prestigious dignity of patrikios he was granted), twice fled back to Samuel and paid for his loyalty to the Bulgarian cause with imprisonment ${ }^{30}$, or the case of Elemag in Thessaloniki, who as early as 1018 or 1019, together with the patrikios Gavra, made an attempt to restore 'Bulgarian authority ${ }^{31}$.

of the patronymic Gavra, see D. Polemis, The Doukai. A Contribution to Byzantine Prosopography, London 1968, p. 120).

${ }^{26}$ Scylitzes-Cedrenus, p. 280-281. On him, see also И. Божилов, Българите..., p. 305, № 338; Й. АНДРеЕВ, И. ЛАЗАРОВ, П. ПАВЛОВ, Кой кой е.., p. 177-178.

${ }^{27}$ Titles of the first order from the hierarchy for the 'Bearded Ones' (i.e. non-eunuchs) were those within the range patrikios to magistros (in ascending order of precedence). Above them were the titles of the higher 'imperial' echelon (zoste patrikia to kaisar) and below them were the titles from the middle echelon of the Byzantine hierarchy, the highest of which - protospatharios, was still considered significant enough during this period so as to be granted to strategoi and various high-ranking officials. See, e.g., Н. Кънев, Византийският йерархичен модел..., p. 153-154.

${ }^{28}$ Scylitzes-Cedrenus, p. 292. On them, see also И. Божилов, Българите..., p. 305, № 339, 327, № 395 and 346-347, № 431. It is quite possible, although it is not expressly referred to, that they also received, like Nikulitsa the Younger, honorific titles by Basil II, for example protospatharios or spatharokandidatos, as Skylitzes notes they were 'honoured in a royal manner'.

${ }^{29}$ Scylitzes-Cedrenus, p. 291, $\gamma$. See also И. Божилов, Българите..., p. 347, № 433.

${ }^{30}$ See Scylitzes-Cedrenus, p. 281, 291.

${ }^{31}$ See note 25 above. 
It should be emphasized that during the time of Basil II, who, by the way, with regard to rank hierarchy exhibited apparent conservatism and respect for its traditions and rules, patrikios remained the title which unambiguously, as in the previous centuries, granted its holder the right to belong to the higher rank elite of the empire, in a way opening the gates to this elite as being basic to it. In actual fact, at that time the number of patrikioi and of the holders of higher titles than that one was not at all so great. During the whole half-century period of Basil II's rule, the total number of the holders of the title of patrikios seems to have remained within only several dozens, while at any particular time - i.e. at one and the same time, the number of patrikioi was of course even more limited $^{32}$. The same holds true to a much greater degree for the magistroi, who were several times less in number than the patrikioi, and at any one time of Basil II's reign there were no more than several magistroi at the same time. Generally speaking, the rest of the Byzantine titles of the first order - vestarches, vestes and anthypatos ${ }^{33}$, provided roughly the same picture. Basil II was most definitely not an emperor who easily conferred high titular distinctions either in Byzantium or beyond it. In Byzantium itself at his time, the rank promotion of the highest ranking Byzantine dignitaries usually reached its limit with the titles of patrikios and anthypatos. It was only on rare occasions that some of the most successful and closest to the emperor's royalty army chiefs, courtiers and high-ranking state officials - such as Nikephoros Ouranos or Constantine Diogenes - were elevated to the rank of magistros, vestarches or vestes. Even the closest relatives of the imperial dynasty in the first quarter of the $11^{\text {th }}$ century were patrikioi - Basil Argyros, whose daughters, as the basileus's nieces, were used by Basil II to forge marriage alliances with the governors and rulers of Venice and Georgia, as well as his brother, the Eparch of Constantinople and future emperor Romanos III Argyros - and no one in the empire thought their titles did not correspond to their

\footnotetext{
${ }^{32}$ On the holders of the title of patrikios in this period known from the sources, see R. Guilland, Patrices du règne de Basile II et Constantin VIII, JÖB 20, 1971, p. 83-108. It is sphragistical data that allows us to form a relatively precise idea of the number of patrikioi: in any case for the period under consideration it remains a double-digit number. Seе Н. Кънев, Приносът на сфрагистиката за разкриване девалвацията на византийските почетни титли в йерархията на т. нар. система на предимство от средновизантийския период - примергт с титлите магистьр и патрикий (границата на VIII/IX - границата на XI/XII в.), ИП 68, 5/6, 2011, p. 265-272.

${ }^{33}$ On them, see R. Guilland, Etudes sur l'histoire administrative de l'empire byzantin. Proconsul, àv $\theta \dot{\pi} \pi \alpha \tau о \varsigma$, REB 15, 1957, p. 5-41; Н. Кънев, Византийската титла вест и нейната еволюиия през XI в., ЕКЧ 10, 2, 2007, p. 92-106; IDEм, Византийските титли вестарх и протовестарх и приносът на сфрагистиката за съставяне на листа на техните носители (втора половина на X - началото на ХІІ в.), АДСВ 38, 2008, p. 135-163. See also Н. Кънев, Приносът на сфрагистиката..., p. 269.
} 
high standing ${ }^{34}$. Patrikioi and/or anthypatoi were also the heads of some of the greatest and most influential families of Byzantine dynatoi in the first quarter of the $11^{\text {th }}$ century, such as Bardas Phokas ${ }^{35}$, Basil Skleros ${ }^{36}$ or John Kourkouas ${ }^{37}$.

In his foreign policy, Basil II used the awarding of honorific titles very carefully and for him this was far from being a formal, still less - obligatory, addition to the treaty relations with a particular Byzantine ally or vassal. For example, outside of Bulgaria, in the Balkan Peninsula Basil II only conferred a Byzantine honorific title on the Croatian prince Stephan Držislav (969-997; a king since 988) whom he granted the title of patrikios. Interesting in this case is the fact that Basil granted the high title to the Croatian ruler as part of his efforts to gain him as an ally of the empire particularly against Samuel's Bulgaria and in response to the latter's strengthening position in the Western Balkans ${ }^{38}$.

Not very numerous either were the cases of awarding Byzantine titles by Basil II to foreign rulers and aristocrats in Italy. At that time, in relation to the strategic partnership Basil II was establishing with Venice in the Adriatic Sea at the end of the $10^{\text {th }}$ and the beginning of the $11^{\text {th }}$ century, Basil II for the first time in the history of the Byzantine-Venetian relations granted Venetian doges titles belonging to the Byzantine titular ranks of the first order. Thus, in 998 he awarded the then doge, Pietro II Orseolo, the high titles of anthypatos and patrikios, and later - his elder son and co-doge Giovanni (the husband of the emperor's niece Maria Argyrina) the title of patrikios, and after Giovanni's death probably also Pietro II Orseolo's younger son and successor as doge Ottone Orseolo (1009-1026) ${ }^{39}$. Also, during Basil II's reign, Byzantine honorific titles were only conferred on some of the Longobardian rulers in South Italy who acknowledged Byzantine suzerainty such as Manso I, duke of Amalfi (966-1004), who was patrikios, or his successor John II who was elevated to the rank of anthypatos ${ }^{40}$. The rulers of Amalfi were considered some of the important Byzantine vassals and allies in South Italy, and in a later period even two of them - John II and John III, were awarded the higher title of vestes ${ }^{41}$. As an anthypatos and patrikios at the time of Basil II can

\footnotetext{
${ }^{34}$ Skylitzès, p. 296, 313. See also J.-F. Vannier, Familles byzantines. Les Argyroi (IX ${ }^{e}-X I I^{e}$ siècles), Paris 1975, p. 9-41.

${ }^{35}$ R. Guilland, Patrices..., p. 84.

${ }^{36}$ Skylitzès, p. 309, 321. He was the husband of Roman and Basil Argyros' sister Pulcheria, and was later elevated by Roman III to the rank of magistros.

${ }^{37}$ R. Guilland, Études..., p. 13.

${ }^{38}$ On this problem, see Н. Кънев, Византинобългарски студии..., p. 66-67.

${ }^{39}$ R. Guilland, Patrices..., p. 87; Н. Кънев, Византинобългарски студии..., p. 69-70. After them, the title of patrikios would only be granted much later to the doge Domenico Contarini (1043-1071) by Emperor Constantine IX Monomachos (1042-1055).

${ }^{40}$ Seе Н.П. Скаваланович, Византийское государство и церковь в ХI в., Санкт-Петербург 1884 , p. 155 , note 3 .

${ }^{41}$ See ibidem, 154 and note 14,155 and note 3 .
} 
also be mentioned Duke Marino II (968-997), but he had actually received his titles already during the reign of John I Tzimiskes ${ }^{42}$.

In line with the Byzantine traditions of the time, Basil II used the awarding of imperial rank distinctions to a greater degree in his Eastern policy, and in some cases there was an exact copying of the model provided by the course of action pursued towards Bulgaria in 971 and 1018. Between 1016/1017 and 1021/1022 the ruler of Vaspurakan, Senekerim-Hovhannes Artsruni, resettled with his family in Byzantium and submitted his state to Emperor Basil II receiving in exchange the title of magistros and the lifetime possession of the Byzantine cities of Sebasteia, Larissa and Abara ${ }^{43}$. Analogous was the case of HovhannesSmbat III (1017-1041) who was forced in 1021/1022 to bequeath his lands to the empire, for which he was guaranteed their lifetime possession and was granted the title of magistros ${ }^{44}$.

In this respect Byzantium's policy was certainly based not only on the 'Bulgarian precedents' but also on previous Armenian and Georgian ones of the $10^{\text {th }}$ century. It was already Nikephoros II Phokas who compensated the successors to the principality of Taron annexed by him by granting each of them the title of patri$k_{i o s}{ }^{45}$, while Basil II himself in 990 even awarded the most powerful among the Georgian rulers of the time, David III (Bagrationi), Prince of Tao (961-1001), the rank of kouropalates, having forced him before that to bequeath to him his principality ${ }^{46}$. Yet, unlike the way Basil II acted towards Bulgaria, in most of these cases besides the high titles, the particular Armenian or Georgian rulers either received territorial compensation in the form of lifetime possession or retained lifetime authority over their lands, which were to come under direct Byzantine administration only after their death.

As part of Basil II's Eastern policy, in 1001 the Georgian king Gurgen II (c. 975-1008) was honoured with the rank of magistros, and his son - Bagrat III, the future king of united Georgia (1008-1014) - was elevated to the dignity of kouropalates ${ }^{47}$. Basil II also granted the distinction of patrikios to prominent Georgian and Armenian aristocrats such as Chortuanel, a nephew of the famous

${ }^{42}$ R. Guilland, Études..., p. 12.

${ }^{43}$ There is a discrepancy in the sources regarding the title Senekerim was granted. According to Skylitzes, Basil II made him patrikios and strategos of Cappadocia, but the Armenian sources and Kekaumenos mention that he received the title of magistros. See SкүLitzès, p. 296; Кекавмен, Советы и рассказы. Сочинение византийского полководиа ХІ века, еd. Г.Г. ЛитАврин, Москва 1972, p. 282. С. К.Н. ЮзБАшян, Армянские государства..., р. 150-156; В.П. СТЕПАНЕНКО, О причинах и датировке передачи Васпуракана Византии, ВВ 38, 1977, р. 72-79.

${ }^{44}$ Seе К.Н. ЮзБАшян, Армянские государства..., p. 157-159.

${ }^{45}$ SкyLitzès, p. 234-235. See also К.Н. ЮзБАшян, Армянские государства..., p. 125.

${ }^{46}$ See Н. Кънев, Куропалати..., p. 82, 90 and note 10 (and the sources given there).

${ }^{47}$ Seе М. ЛордкиПАнидзЕ, История Грузии XI- начала ХІІІ века, Тбилиси 1974, p. 50 and note 13. 
general and later Athonite monk John Tornikios - at the end of the $10^{\text {th }}$ century, the cousins of the first Bagrat and Chortuanel, as well as the brothers Pherse, Pheudate and Pakourian - at the very beginning of the $11^{\text {th }}$ century ${ }^{48}$. It is also known that during the military operations against Bulgaria at the beginning of the $11^{\text {th }}$ century the Georgian Theodate Iberos (the Iberian), who was a holder of the dignity of patrikios, distinguished himself ${ }^{49}$.

The awarding of members of the Armenian and Georgian aristocracy Byzantine titles by Basil II aimed at confirming the Byzantine influence and where possible - the direct authority, of the empire over particular Armenian or Georgian regions, and it was not fortuitous that the persons who received titular dignities joined the ranks of the Byzantine aristocracy. It is evident that in its policy in the East, too, Basil II followed a course of action which to a great extent was analogous to the model he followed in conquering the Bulgarian lands.

The survey of the awarding of Byzantine titles at the time of Basil II makes it possible to trace the sheer scale of his actions in this respect with regard to the Bulgarians, and hence the big scale of the concessions within the Byzantine rank hierarchy this emperor was ready to make for the sake of the final subjugation of Bulgaria. The number of the Bulgarians holders of high titles was considerable enough when expressed as a percentage of the total number of the holders of titles of the first order in Byzantium for this period. Most probably it was about a tenth, and possibly even higher. Viewed from the perspective of foreign policy, this number exceeded at least twice all the other cases of awarding significant titular distinctions outside of Byzantium in pursuing Basil II's European policy, and if not higher, it is at least comparable in quantitative terms to the granting of high titles in following the Eastern policy of the empire during Basil II's reign. Never before, as well as never after that did a Byzantine emperor use the awarding of high honorific ranks on such a big scale regarding the Bulgarians as Basil II did, but certainly the highly significant dimensions of this incorporation of members of the Bulgarian elite into the highest echelons of the Byzantine rank hierarchy was entirely within the context of the destruction of the Bulgarian state and submitting Bulgaria to the authority of the Byzantine Empire.

\footnotetext{
${ }^{48}$ Skylitzès, p. 283-284. See also R. Guilland, Patrices..., p. 92; К.Н. Юзбашян, Армянские государства..., p. 138, 142, 145-146.

${ }^{49}$ See R. Guilland, Patrices..., p. 95-96.
} 


\section{Bibliography}

\section{Primary Sources}

Ioannis Scylitzes, Georgios Cedrenus, Historiarum compendium, [in:] Fontes Graeci Historiae Bulgaricae, vol. VI, ed. G. Cankova-Petкova et al., Serdicae 1965, p. 198-340.

Jean Skylitzès, Empereurs de Constantinople, trans. B. Flusin, comm. J.-C. Cheynet, Paris 2003.

KeKavmen, Sovety i rasskazy. Sočinenie vizantijskogo polkovodca XI veka, ed. G.G. LitAVRIN, Moskva 1972.

Lev Diakon, Istorija, ed. G.G. Litavrin, Moskva 1988.

\section{Secondary Literature}

Andreev J., Lazarov I., Pavlov P., Koj koj e v srednovekovna Bălgarija, Sofija 2012.

BožILov I., Bălgarite văv Vizantijskata imperija, Sofija 1995.

Cheynet J.-C., Dévaluation des dignités et dévaluation monétaire dans la seconde moitié du XIe s., "Byzantion. Revue internationale des études byzantines" 53, 1983, p. 469-471.

Cheynet J.-C., Patricienne à ceinture: une femme de qualité. Au cloître et dans le monde. Femmes, hommes et sociétés (IXe-XVe siècle), [in:] Mélanges en l'honneur de Paulette L'Hermite-Leclercq, Paris 2000, p. 179-187.

Guilland R., Contribution à l'histoire administrative de l'empire byzantin. La patricienne à ceinture, $\dot{\eta} \zeta \omega \sigma \tau \grave{\eta} \pi \alpha \tau \rho \iota \kappa i \alpha$, "Byzantinoslavica. Revue internationale des études byzantines" 32, 1971, p. 269-275.

Guilland R., Études sur l'histoire administrative de l'empire byzantin. Proconsul, $\alpha \dot{\alpha} \theta \dot{\pi} \pi \alpha \tau o \varsigma$, "Revue des études byzantines" 15, 1957, p. 5-41.

Guilland R., Patrices du règne de Basile II et Constantin VIII, "Jahrbuch der Österreichischen Byzantinistik" 20, 1971, p. 83-108.

JuzbašJan K.N., Armjanskie gosudarstva epohi Bagratidov i Vizantija IX-XI vv., Moskva 1988.

KăNEv N., Kuropalati izvăn Vizantijskata imperija prez IX-XI vek, “Епохи” / "Epohi” 11, 1/2, 2003, p. 79-93.

KăNev N., Prinosăt na sfragistikata za razkrivane devalvacijata na vizantijskite početni titli i jerarhijata na t.nar. sistema na predimstvo ot srednovizantijskija period - primerăt s titlite magistăr i patrikij (granicata na VIII/IX v.), "Исторически преглед" / "Istoričeski pregled” 68, 5/6, 2011, p. $265-272$.

KăNev N., Titlata proedăr kato čast ot părvorazrednite početni titli văv Vizantija X-XI v. Proedri i protoproedri, zasvidetelstvani po sfragistični danni, [in:] N. KăNEv, Vizantinobălgarski studii, Veliko Tărnovo 2013, p. 144-227.

KăNev N., Vizantijskata titla magistăr prez IX - načaloto na XII v. Prinosăt na sfragistikata za săstavjane na lista na nositelite na titlata magistăr, [in:] N. KăNEv, Vizantinobălgarski studii, Veliko Tărnovo 2013, p. 228-298.

Kănev N., Vizantijskata titla patrikija-zosti (IX-XI v.). Prinosăt na sfragistikata za popălvane na listata na nositelite na titlata, "Историкии" / "Istorikii" 4, 2011, p. 173-198.

KăNEv N., Vizantijskata titla vest i nejnata evoljucija prez XI v., "Епископ Константинови четения" / "Episkop Konstantinovi Četenija” 10, 2, 2007, p. 92-106. 
KăNEV N., Vizantijskijat jerarhičen model ot IX-XI v., “Античная древность и средние века” I "Antičnaja drevnoctj i srednie veka" 39, 2009, p. 142-163.

KăNEv N., Vizantijskite titli vestarh i protovestarh i prinosăt na sfragistikata za săstavjane na lista na tehnite nositeli (vtora polovina na X - načaloto na XII v.), “Античная древность и средние века" / "Antičnaja drevnoctj i srednie veka" 38, 2008, p. 135-163.

LEMERLe P., Roga et rente d'état aux Xe-XIe siècles, "Revue des études byzantines" 25, 1967, p. 77-100.

LoRdKIPANIDZE M., Istorija Gruzii XI-načale XIII veka, Tbilisi 1974.

Nikolov G., Edno svedenie za bălgarskata istorija: Ioannes Scylitzes (Cod. Ambr. c. 279), [in:] Civitas Divino-Humana. V čest na professor Georgi Bakalov, Sofija 2004, p. 335-338.

Polemis D., The Doukai. A Contribution to Byzantine Prosopography, London 1968.

Săвотіnov A., Bălgarija pri car Samuil i negovite naslednici (976-1018), vol. I, Sofija 2008.

SeIBt W., Die Skleroi. Eine prosopographisch-sigillographische Studie, Wien 1976.

Skabalanovič N.P., Vizantijskoe gosudarstvo i cerkov' v XI v., Sankt-Peterburg 1884.

SLAvova T., Vladetel i administracija v rannosrednovekovna Bălgarija. Filologičeski aspekti, Sofija 2010.

Stepanenko V.P., O pričinach i datirovke peredači Vaspurakana Vizantii, “Византийский временник"/ "Vizantijskij Vremennik" 38, 1977, p. 72-79.

Vannier J.-F., Familles byzantines. Les Argyroi (IXe-XII siècles), Paris 1975.

Vogt A., Histoire des institutions: note sur la patricienne à ceinture, "Échos d'Orient" 37, 1938, p. 352-356.

Zlatarski V.N., Istorija na bălgarskata dăržava prez srednite vekove, vol. I.2, Sofija 1971.

\begin{abstract}
This article examines the question about the policy of honouring members of the Bulgarian imperial family and Bulgarian aristocracy with Byzantine honorific titles pursued by Emperor Basil II Boulgaroktonos (976-1025) in the course of the conquest of Bulgaria. It outlines the scale of this policy of Basil II - its goals and the reasons for adopting it. A review of the place and the importance of the particular titles in the rank hierarchy of Byzantium is presented. The comparison with other regions and cases of conferring Byzantine honorific titles clearly shows how crucially important the conquest of Bulgaria was: it is evident from the concessions the Emperor was ready to make to the Bulgarian ruling elite.
\end{abstract}

Keywords: Bulgaria, Byzantium, Emperor Basil II Boulgaroktonos, Byzantine honorific titles, Byzantine rank hierarchy.

\title{
Nikolay Kanev
}

"St. Cyril and St. Methodius" University of Veliko Tărnovo Department of Ancient and Medieval History Faculty of History 2 Teodosiy Tarnovski Str. 5000 Veliko Tarnovo, Bulgaria kanev_nikolay@hotmail.com 